\title{
LEISURE TIME AND ACTIVITY OF SENIORS AS EXEMPLIFIED BY THE CZESTOCHOWA CENTRE FOR SENIOR ACTIVITY
}

\author{
Monika Joanna Nowińska \\ Daniel Bakota \\ Jan Długosz University, Częstochowa, Poland
}

\begin{abstract}
Over the last quarter of a century the changing age structure in Poland could be observed. A significant part of the society is made up of seniors, which enforces senior policies whose mission is to provide model solutions to the problems of the elderly. A wide range of offers makes it possible to encompass any needs of the elderly in different aspects of their existence, including: health, activity/sport, managing leisure time and a number of areas concerning economic, social, cultural, and other problems in order to improve the quality of their lives. The ageing society results in the avalanche of needs, including those related to health. A person of advanced age becomes less efficient with health problems appearing on the physical and mental plane, which is associated with the financial burden of the State, queues in healthcare and many other, equally unpleasant effects. To a large extent, this could be prevented by providing the elderly help in maintaining physical fitness and mental wellbeing. The aim of this paper is to draw attention to the fact how the elderly manage their leisure time, which, at the same time, will be indicative of their needs in this respect. The examined group (50 people) are the elderly - women and men of different educational backgrounds, aged 60 or more who most often already have fixed income. From among these fifty, 25 people spend their leisure time in the Czestochowa Centre for Senior Activity, and the remaining 25 respondents - for comparison - are people who act on their own in order to fill their spare time for themselves. The method used for the survey was a diagnostic opinion poll, and the research tool - a questionnaire survey.
\end{abstract}

Keywords: leisure time, seniors, activity, needs.

\section{Introduction}

The completeness of the spiritual and material wealth, which people have collected, enriched and multiplied over the years has allowed for culture to be created. The motive which has made this act possible is leisure time. The ways of taking advantage of leisure time throughout history have been different in quality and depended on a number of factors. However, one cannot specify the values which leisure time is guided by. In every culture using this time looks differently, which has resulted in many theories of leisure time encompassing its different aspects and values. The attempts to define it revolved around 
philosophy, mythology and theology. It was only between the 19th and 20th century that the focus shifted to scientific deliberations on the subject (Truszkowska-Wojtkowiak, 2012).

The definition of leisure time in reference books is variously captured, but the meaning is the same. The simplest way to put it - it is the time when a person does not work, does not carry out their duties and only engages in what they like and freely want to do during this time (Pięta, 2014).

There are a lot of conditions which influence the quality of spending one's leisure time. These include, among other things: age, sex, independence, marital status, place of residence, health, education, income or social position.

The period of old age is the time when people in view of the fact that they have reached the retirement age, i.e. are not engaged in professional activity any more - have a lot of leisure time. According to the demographic forecasts in the year 2019 the population of elderly persons will constitute $27 \%$ of the Polish society, i.e. more than 9,621,000 seniors (Pikuła, 2013).

A significant increase in the number of elderly people has contributed to the considerable development of activities in support of that group at every level of life. In view of the above, attending to the quality of seniors' life and filling their leisure time, which accounts for a significant part of their lives, started to be taken care of. A lot of institutions, organizations, and activities were established in support of the elderly, which while filling their leisure time also attend to their fitness, spiritual and cultural experience, personal growth, entertainment or tourist and recreational activity. They take actions that have a high impact on their healthy lifestyle, which for a long time now has been downright trendy, preferred by a significant part of the population, including seniors.

Activity during the period of old age is particularly important. It is on this activity, among other things, that it depends how the general public perceives senior citizens, whether it accepts them, perceives as role models, or considers a useless, infirm and hampering group of the population. The concept of activity has taken on a comprehensive meaning. In literature it has been divided into the following groups:

- $\quad$ solitary - a senior is mainly engaged in reading books and the press, watching television, developing their hobbies, interests, all activities focus on one person;

- formal - this group includes volunteering, local and community works, activity in social associations;

- $\quad$ informal - meeting friends, neighbours, ongoing contact with a family (Pikuła, 2012). 
A great part in seniors' life is played by physical and motor activity, too. A leisure form such as dancing, games and motor activities is particularly desired by the elderly (Matusiak, 2006). Yoga has become popular with seniors (a training of the body and mind with elements of meditation); as well as attending fitness classes, which are specially prepared and organized for the elderly people; endurance classes at home and organized in indoor facilities (Marchewka, 2012), in a swimming pool; and also weight training e.g. outdoors. These are basic types of exercise which allow an elderly person to keep fit and healthy while - in the case of trainings in groups - enabling contact with people. They also inspire to take more action, stimulate ambitions, encourage people to take up something new, as well as prevent social isolation and loneliness.

Another, as a matter of fact very popular, form of spending one's leisure time in an active way is volunteering. Seniors who feel great despite their age, often dedicate their time to help the elderly who are not in good physical or mental shape. They offer their assistance by e.g. cleaning the house or doing shopping for the people who are ill or unable to cope. Walking or watching films together has a good influence on a lonely person as well as on the volunteer, who has a sense of doing something good. Volunteering can also refer to seniors visiting the ill in hospices or lonely persons in hospitals. It is also children in hospitals or children's homes who benefit from volunteering offered by elderly people, i.e. reading books, help studying - private lessons, walking together, talking, benefiting from the wisdom and advice of the elderly, also on the basis of a mutual transaction.

Tourism and recreation have become another stimulus to the seniors' activity (Marzec, 2016). The combination of learning about the world, people, cultures with great fun have turned out to be an ideal solution for seniors. This age group also has a significant impact on the tourist industry (Alen et al., 2016; Cristobal-Fransi et al., 2017). Additionally, at present there are a lot of actions aimed at adapting areas, degraded as a result of human activity, for tourist and recreational purposes, which can later be used by everyone, including senior citizens (Dwucet, 2016).

Cultural and educational classes have also met with increasing success. Seniors make use of cheaper or sometimes free tickets and become acquainted with culture available at cinemas, theatres, concert halls, concerts, festivals, operas, museums, art galleries, exhibitions or lectures (Szarota, 2009).

Recently, Universities of the Third Age have become valuable, where the opportunity to deepen their interests, mainly in the educational aspect, has become common among seniors. The first such university was established in France in 1973 owing to P. Vellas. Organizing seminars, conducting foreign language courses, lectures and discussions are their fundamental concept (Orzechowska, 2001). The universities are a good place conducive to 
integration, making new contacts and friends, which can be further developed outside of classes. Other, equally important, objectives include: improving the conditions and quality of life of the elderly, physical, mental and intellectual activation of the elderly - essential to maintain cognitive function for as long as possible (Bulska, 2003). The Universities of the Third Age operate at higher education establishments, cultural, scientific and social associations, as well as at social welfare centres. In Poland there are about 200 of them. In other countries, like Italy or Germany, educational facilities for seniors are dubbed differently, e.g. Intergenerational Universities, Universities of Leisure Time, Senior Academies or Senior Universities (Zych, 2010).

Spending leisure time differs depending on whether it takes place in cities or villages. People from villages may benefit from the goods offered by cities, but the journey or transport of an elderly person to such an institution could be an impediment.

The main activities of senior citizens in rural areas are, among others, gardening (Vespalec et al., 2017), including in allotment gardens, often working on the farm, helping children with the care of their grandchildren, religious practice, sleep (Borkowska-Kalwas, 2002), making preserves, mushroom picking, taking care of the house and yard, or feeding animals.

To sum up, the elderly have a wide range of opportunities to spend their leisure time regardless of the place where they live (village, city). They can use it for sightseeing, travelling (Omelan et al., 2016), learning, studying, making art, culture, gaining new experiences, talents, inspirations, integration with the society, helping others, getting to know their own potential - thus proving, to themselves and others, that an old person doest not always equal somebody who is lonely, passive, silent, maladjusted (Kuchcińska, 2000), unpleasant, pessimistic, infirm, stubborn, parochial, redundant and lifeless.

\section{Materials and methods}

The study was conducted in 2017. The examined group are people between 64 and 89 years of age. Some of these people: 15 women and 10 men - are members of the Częstochowa Centre for Senior Activity (CCSA), the remaining ones: 15 women and 10 men - do not use the services of this institution. A method used for the survey was a diagnostic opinion poll, and the research tool a questionnaire survey. 


\section{Results and discussion}

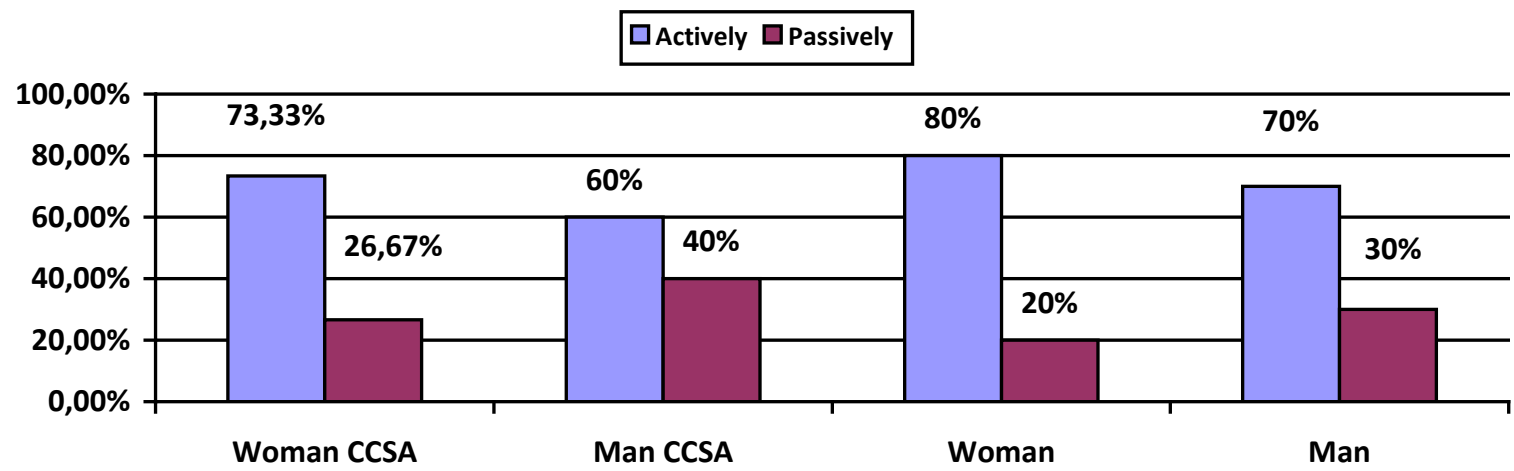

Figure 1. Forms of spending leisure time by seniors (\%)

Figure no. 1 shows that $73.33 \%$ of women and $60 \%$ of men from CCSA and $80 \%$ of women and $70 \%$ of men outside of CCSA spend their leisure time actively. The remaining ones, i.e. $26.67 \%$ of women and $40 \%$ of men who are members of the institution and $20 \%$ of women and $30 \%$ of men who are not members of the facility, spend their leisure time in a passive way. The vast majority of the respondents in both groups prefer the active form of spending leisure time. This is especially noticeable in the case of women. A small percentage of people spend their leisure time passively, i.e. do not engage in any physical activity.

\section{$\square$ Woman CCSA $\square$ Man CCSA $\square$ Woman $\square$ Man}

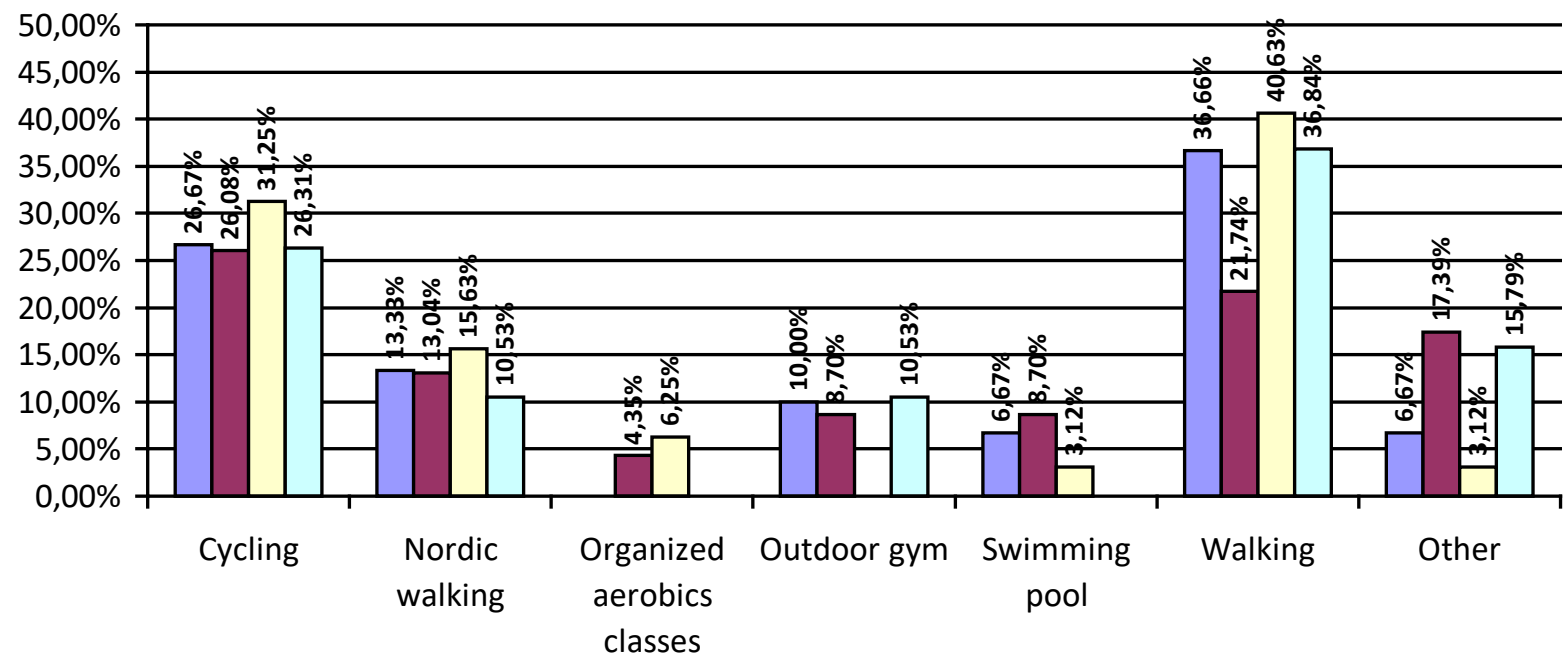

Figure 2. Activities which seniors engage in most often in their leisure time (\%)

A significant proportion of seniors engage in physical activity, which as a result allows them to maintain their physical well-being and keep fit, and, in 
addition, allows them to maintain social contacts, which prevents withdrawal or isolation of the elderly. Among the proposed activities included in the survey (it was possible to indicate more than one answer), walking was the most popular among seniors in both groups. In the examined group from CCSA as many as 11 women (which accounted for $36.66 \%$ of answers) and 5 men (21.74\%) prefer such form of activity. In the second group as many as 13 women $(40.63 \%$ of answers) and 7 men (36.84 \%) opt for walking as an activity practised most frequently. Cycling tours are ranked the second and nordic walking takes the third place (see figure 2).

\section{$\square$ Woman CCSA $\square$ Man CCSA $\square$ Woman $\square$ Man}

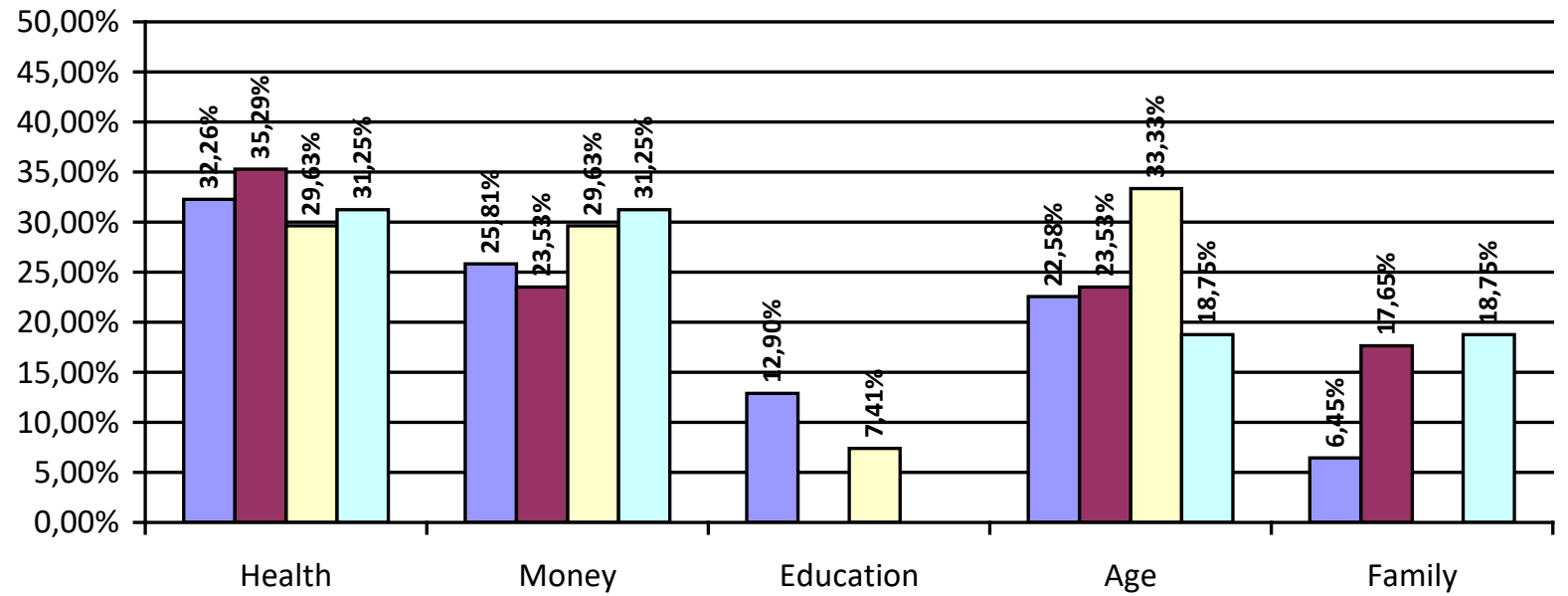

Figure 3. Factors which seniors need more to be able to enjoy leisure time (\%)

In the next question, where more than one answer was also possible, 10 women (accounting for $32.26 \%$ of answers) and 6 men (35.29 \%) of CCSA and 8 women $(29.63 \%)$ and 5 men $(31.25 \%)$ outside of CCSA, in order to enjoy their free time fully need health. The subsequent 8 women $(25.81 \%)$ and 4 men (23.53 \%) of CCAS and 8 women (29.63\%) and 5 men (31.25\%) who do not use the services of the institution think that they need more money to feel truly happy. The issue of education was pointed out by 4 women $(12.90 \%)$ from CCSA and 2 women $(7.41 \%)$ from the second group. The factor of the age of seniors proved equally important in this regard, 7 women $(22.58 \%)$ and 4 men (23.53\%) from the institution and 9 women (33.33\%) and 3 men (18.75\%) from the second group believe that, in order to enjoy one's free time in the period of old age, it would be good to be much younger. The subsequent 2 women $(6.45 \%)$ and 3 men (17.65 \%) from CCSA and none of the women and 3 men $(18.75 \%)$ outside of CCSA claim that a family would make them truly happy (see figure 3). 
In connection with the last-mentioned factor, the figure clearly shows that it is the men who miss the family more in both groups than the women. The additionally provided answers indicate that these are single men who have never had a family or those whose wife died and children live far away.

The next figure shows whether the activities which seniors engage in are satisfying for them, if they enjoy the activities practised.

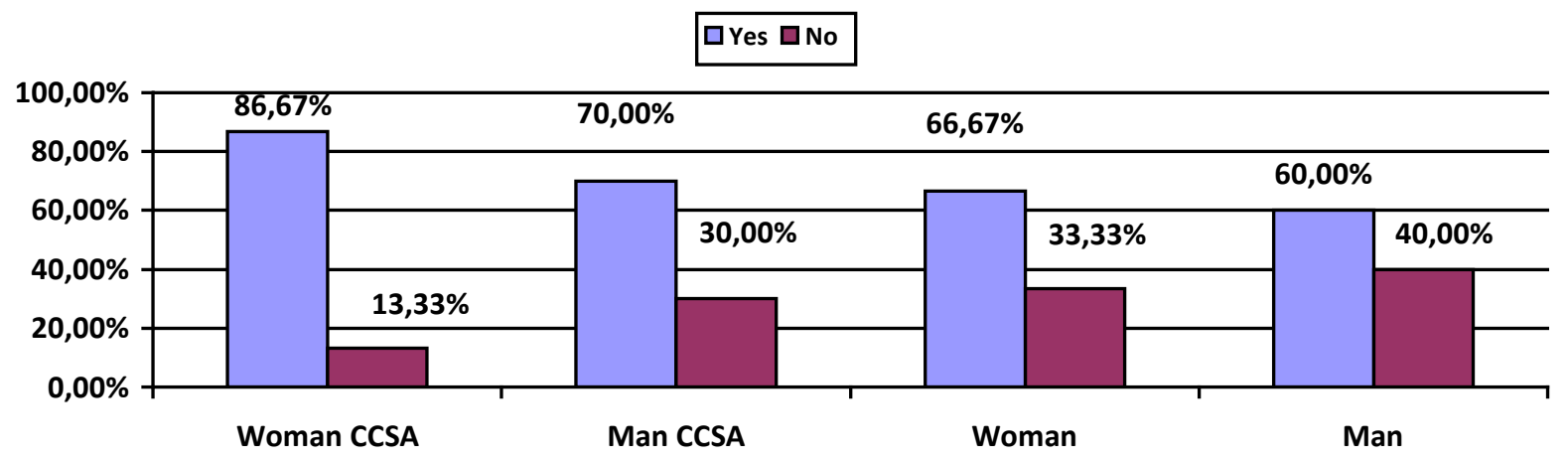

Figure 4. Satisfaction with the forms of activities practised by seniors in their leisure time (\%)

$86.67 \%$ of women and $70 \%$ of men from the institution and $66.67 \%$ of women and $60 \%$ of men outside of CCSA are satisfied with the form of activity they practise in their leisure time. Dissatisfaction was expressed by $13.33 \%$ of women and $30 \%$ of men from the institution and $33.33 \%$ of women and $40 \%$ of men from the second group. The main reasons for dissatisfaction with the forms of spending leisure time are the factors analysed above, which, as it turned out, influence the quality of seniors' life. These include among others: age, health condition, income and education.

The results of research obtained (taking into account first of all activities undertaken by the seniors in their free time) are similar to those obtained in 2015 by Blanka Gosik who conducted the study among a much larger group (400 inhabitants of Łódź at the age of over 60 years old were examined). One can say that the elderly are keen on quite similar forms of physical activity. The seniors of Łódź province, taking into account - as the author of the article described sports activity most often pointed to cycling. Nordic walking was ranked the second and swimming the third. In turn, most respondents who are not engaged in sports activity pointed to walking (83.4 \%) (Gosik, 2015). However, most importantly of all, the elderly actively spend their leisure time. All the more so because numerous studies have confirmed the salutary effect of physical activity on the life of the elderly people (Gregg et al., 2003). Physical activity in seniors, among other things, reduces the risk of their death, increases life expectancy (Stessman et al., 2009) and significantly reduces the incidence rate of chronic diseases, including type 2 diabetes (Demakakos et al., 2010). 


\section{Conclusions}

People in the period of old age have a lot of leisure time. The vast majority of the people examined are able to manage their time dividing it into the active forms of leisure and the rest. Seniors, in order to maintain their physical wellbeing and keep fit go for walks, cycle, work out in outdoor gyms. When taking a rest the elderly most often watch television, listen to the radio, read books and the press, play cards with their neighbours.

In the case of people who do not take advantage of any offers for seniors, one must consider whether such people do not have time indeed to take part in such projects or ventures, or are just unable to manage it. Other reasons could be e.g. lack of knowledge regarding the offers prepared by institutions for the benefit of seniors, fear of something new for them, fear of being rejected by the group, and in extreme cases an elderly person's retreating from the world, withdrawal, and even the result of exclusion or marginalisation of an individual. One must consider which actions must be taken to be able to reach the biggest possible number of the elderly.

The choice of a form of activity to a large extent is also affected by interests and passions of the elderly people. Some of the respondents like singing, others enjoy dancing. Some are interested in space, others walk in the mountains, and still others play the stock market. Each of them is different and each does what they like. The most popular activities practised are walks, cycling tours and nordic walking. This is noteworthy as improvement in the functioning of human mental and physical health promotes preventive health care. The aim is optimal functional improvement, taking into account the individual context of each person (Ortenburger et al., 2017; Wąsik \& Wójcik, 2017).

There are several factors which are inherent in the period of old age. Some of them make it difficult for the elderly to be active with all of them to a lesser or greater extent influencing the quality of their life. These include the ones examined in the study: health condition, age, income, lack of family, and even the level of education.

Despite all the obstacles that the elderly face and difficulties related to their daily routine, a significant portion of the people examined claimed that they are satisfied with their current age, which can be associated with all life events, barriers they have overcome in their lifetime and their memories. Most of the people examined feel satisfied with their life and activities practised. 


\section{References}

Alen, E., Losada, N., \& Domingues, T. (2016). The Impact of Ageing on the Tourism Industry: An Approach to the Senior Tourist Profile. Social Indicators Research, 127 (1), 303-322, DOI: 10.1007/s11205-015-0966-x.

Borkowska-Kalwas, T. (2002). Sposoby spędzania czasu wolnego. In: Halik, J. (Eds.), Starzy ludzie w Polsce. Spoleczne i zdrowotne skutki starzenia się społeczeństwa (pp. 52-61). Warszawa: Instytut Spraw Publicznych.

Bulska, J. (2003). Promocja zdrowia ludzi starszych na progu XXI wieku. In: Marzec-Holka, K. (Eds.), Pomoc społeczna, praca socjalna: teoria $i$ praktyka (pp. 584-594). Bydgoszcz: Wydawnictwo Akademii Bydgoskiej.

Cristobal-Fransi, E., Ferrer-Rosell, B., \& Daries-Ramon, N. (2017). Segmentation of seniors based on products bought on the Internet: impact on tourism industry. Cuadernos de Turismo, 40, 175-201.

Demakakos, P., Hamer, M., Stamatakis, E., \& Steptoe, A. (2010). Low-intensity physical activity is associated with reduced risk of incident type 2 diabetes in older adults: evidence from the English Longitudinal Study of Ageing. Diabetologia, 53 (9), 18771885.

Dwucet, K., Rzetala, M., \& Snieszko, Z. (2016). Regeneration and adaptation of strongly anthropogenically altered areas for recreation and tourism purposes - case study of the Silesian Upland. $3^{\text {rd }}$ International Multidisciplinary Scientific Conferences on Social Sciences \& Arts SGEM 2016. Book 2. Political Sciences, Law, Finance, Economics \& Tourism. Conference Proceedings, vol. IV. Economics \& Tourism, Sofia, Bulgaria, 551558.

Gosik, B. (2015). Rekreacja i aktywność ruchowa starszych osób. Przykład mieszkańców województwa łódzkiego. In: Janiszewska, A. (Eds.), Jakość życia ludzi starych wybrane problemy (pp. 151-163). Łódź: Wydawnictwo Uniwersytetu Łódzkiego.

Gregg, E. W., Cauley, J. A., Stone, K., Thompson, T. J., Bauer, D. C., Cummings, S. R., \& Ensrud, K. E. (2003). Study of Osteoporotic Fractures Research Group: Relationship of changes in physical activity and mortality among older women. Journal of the American Medical Directors, 289, 2379-2386.

Kuchcińska, M. (2000). Postrzeganie ludzi starych przez dzieci i młodzież. In: Marzec-Holka, K. (Eds.), Społeczeństwo. Demokracja. Edukacja. Nowe wyzwania w pracy socjalnej (pp. 376-385). Bydgoszcz: Wydawnictwo Akademii Bydgoskiej.

Marchewka, A. (2012). Aktywność fizyczna - oręż przeciw niepełnosprawności osób w wieku starszym. In: Marchewka, A., Dąbrowski, Z., Żołądź J. A. (Eds.), Fizjologia starzenia się: profilaktyka i rehabilitacja (pp. 386-429). Warszawa: Wydawnictwo Naukowe PWN.

Marzec, A. (2016). Tourism as a form of health and recreation activity of the elderly. 3rd International Multidisciplinary Scientific Conference on Social Sciences and Arts SGEM 2016. Conference Proceedings, Book 1. Psychology and psychiatry, sociology and healthcare, education conference proceedings, vol. 3. Education and Educational Research, 1221-1226, DOI: 10.5593/SGEMSOCIAL2016/B13/S03.160

Matusiak, A. (2006). Aktywność zabawowa podopiecznych Domów Dziennego Pobytu w Zielonej Górze. In: Nowicka A. (Eds.), Wybrane problemy osób starszych (pp. 275282). Kraków: Oficyna Wydawnicza „Impuls. 
Omelan, A., Podstawski, R., \& Raczkowski, M. (2016). Tourist Activity of Senior Citizens (60+) Residing in Urban and Rural Areas. Physical Culture and Sport. Studies and Research, 72 (1), 51-65.

Ortenburger, D., Rodziewicz-Gruhn, J., Wąsik, J., Marfina, O., \& Polina, N. (2017). Selected problems of the relation between pain-immunity and depression. Physical Activity Review, 5, 74-77, DOI: 10.16926/par.2017.05.10

Orzechowska, G. (2001). Aktualne problemy gerontologii społecznej. Olsztyn: Wydawnictwo Uniwersytetu Warmińsko-Mazurskiego.

Pięta, J. (2014). Pedagogika czasu wolnego. Warszawa: Wydawnictwo FREL.

Pikuła, N. (2012). Zdrowie i aktywność społeczna jako determinanty jakości życia osób starszych. In: Zych A. A. (Eds.), Poznać, zrozumieć i zaakceptować starość. Wybór materiałów konferencyjnych (pp. 313-324). Łask: Over Group.

Pikuła, N. (2013). Senior w przestrzeni społecznej. Warszawa: Wydawnictwo BORGIS.

Stessman, J., Hammerman-Rozenberg, R., Cohen, A., Ein-Mor, E., \& Jacobs, J. M. (2009). Physical activity, function, and longevity among the very old. Archives Internal Medicine, 169 (16), 1476-1483.

Szarota, Z. (2009). Seniorzy w przestrzeni kulturalno-edukacyjnej społeczeństwa wiedzy. In: Stopińska-Pająk, A. (Eds.), Edukacja wobec starości - tradycja i współczesność (pp. 77-96). Katowice: Wydawnictwo Uniwersytetu Śląskiego.

Truszkowska-Wojtkowiak, M. (2012). Fenomen czasu wolnego. Gdańsk: Harmonia Universalis - Grupa Wydawnicza HARMONIA.

Vespalec, T., Scholz, P., \& Stara, J. (2017). Gardening as the optional physical activity for seniors. $8^{\text {th }}$ International Scientific Conference on Kinesiology, 316-320.

Wąsik, J., \& Wójcik, A. (2017). Health in the context of martial arts practice. Physical Activity Review, 5, 91-94, DOI: 10.16926/par.2017.05.13

Zych, A. A. (2010). Leksykon gerontologii. Kraków: Oficyna Wydawnicza Impuls. 